\title{
The relation between theory and reality in Eugeniu Coșeriu and José Ortega y Gasset
}

\author{
Cristinel Munteanu ${ }^{\star}$ \\ Faculty of Communication and International Relations, "Danubius" University, Bd. Galați 3, 800654 Galați, Romania
}

\begin{abstract}
Article info
History:

Received October 3, 2019

Accepted October 13, 2019

Published November 7, 2019

Key words:

linguistics

philosophy

theory

reality

empirical study

Abstract

Taking as a starting point a quote about theory attributed to José Ortega y Gasset (1883-1955), a quote which Eugeniu Coşeriu (1921-2002) reproduced distorted in one of his lectures delivered in Romanian (in 1992), I aim - apart from identifying the Spanish philosopher's work from which the respective quote was extracted - at making a presentation of the two scholars' conceptions regarding the relation between theory and reality or, better said, between theory and the facts investigated. At first sight, the two conceptions look similar, especially since the two thinkers frequently create the impression of belonging to the same grand family of thinking. I will try to show in this article both the convergent and the divergent aspects of their conception, also pinpointing some consequences which derive from them, of interest for the philosophy of language, as well.
\end{abstract}

\section{Preliminaries}

On the $11^{\text {th }}$ of March, 1992, on the occasion of being awarded the title doctor honoris causa of the University "Babeş-Bolyai" of Cluj-Napoca, Eugeniu Coșeriu delivered a speech about the principles of linguistics as a science of culture. The respective lecture was recorded and published, in the same year, in the journal "Apostrof" 1 . The topic was not a new one, since the scholar used to present in such circumstances the principles of humanistic research, which permanently guided him (be they implicitly or intuitively, at first) in his scientific activity (Coșeriu, 1992a [=2000b]; 1992b, 1993, 1997b, 1999, 2004a,b).

I will not insist here on the principles as such (that of realism, of humanism, of tradition, of antidogmatism and that of social responsability), which Coșeriu first presented, in an explicit and justified form, in his reception address occasioned by his election, in 1977, as a member of the Academy of Sciences from Heidelberg (Coșeriu, 1977) ${ }^{2}$. I only want to underline the fact that, beyond the expected common core of all these speeches, lectures or conferences, there are-at times-some "variations", as well. This is the reason why, in the first parts of this article, I will only deal with one (probably unique) element, namely a quote from Ortega y Gasset which Coșeriu may have used only in the above mentioned lecture from Cluj; with this in mind, I will also try to present Coșeriu's conception on the relation between theory and the reality of language. After having elucidated the origin of the analysed quote, I aim at determining, in the other parts of my article, the extent to which Coșeriu had the right to resort to Ortega y Gasset as an argument for his statements concerning the application of linguistic theories. Hence, I ought to present in my article-even if broadly-Ortega's conception about the relation between theory and reality, as well.

Since an ethical subject-matter of science is under discussion, Coșeriu invokes-in order to support his linguistic conception-various philosophers who influenced him, more or less, during his scientific

\footnotetext{
${ }^{\star}$ Email address: munteanucristinel@yahoo.com.

${ }^{1}$ Mention must be made that a part of this study (having partially different aims), as an autonomous article, is soon to be published, in an honorary volume edited by some colleagues from the "Babeș-Bolyai" University of Cluj-Napoca.

${ }^{2}$ The last principle, that of social responsibility (or of public utility), is not explicitly formulated in the respective reception address, since Coșeriu may have wanted to present, on that occasion, only the principles of research as such, leaving aside the principle of the scientist seen as a member of a community (or of a "state").
} 
development: Plato, Hegel, Husserl, Leibnitz etc. As he himself confessed later, in a conference delivered in Madrid (see Coșeriu, 1999, p. 41), Coșeriu would discover and start to appreciate José Ortega y Gasset only in the late '50s, in Uruguay, a time when the former's linguistic conception was already well coagulated. Accordingly, Coșeriu would sometimes resort to Ortega, with a view to getting a further confirmation of the ideas which he had shaped (most of them) within the scientific Italian environment (cf. also Munteanu, 2019a).

\section{Theory and empirical study in linguistics}

What is, in fact, Ortega's quote which I will comment in what follows? In his lecture from Cluj, Coșeriu appeals to the Spanish thinker at one point in his speech. Thus, when he discussed the second principle of research, the principle of humanism or that of "primary knowledge" (according to Husserl), Coșeriu states that it has more corollaries, but he only stops at the one which he considers the most important:

"It is the question of the permanent unity between theory and empirical study (in linguistics and in other cultural sciences, but mainly in linguistics, because there have been so many deviations here). It is absurd, if we start from what is bekannt, to create theories independent of facts and then say that if they do not apply to reality, tant pis pour la réalité; no, in this case, the respective theory is faulty, not reality. When speaking about this aberration of the inapplicable theories, the Spanish philosopher Ortega said: «Una teoría que no se aplica no es una teoría, es una estupidez». This is true about facts too: in reality, there is no empirical study without an at least intuitive theory at its basis. A well-done empirical study is therefore also a contribution to theory, just as theory is always a theory of facts, since theory means recognizing the universal in the particular, in the concrete."

(Coșeriu, 2000b, p. 111; [transl. of Coșeriu, 1992a])

Before examining the quote extracted from Ortega's work, I will make some clarifications regarding this topic. Coșeriu had already discussed with various occasions about the dialectical relation between theory and the study offacts, even before that reception address, in 1977, at the Academy of Heidelberg. He had also stated it in Romanian: for instance, in an interview from 1974 given to Nicolae Saramandu ${ }^{3}$ :

"To my mind, theory is not an arbitrary and abstract construction. It is, first of all, the intuition of universal in facts and then the explicit and reflexive formulation of this universal. To me, this means three things: (1) there is no real opposition between the study of facts and the theoretical study. A theory is always a theory of reality and not an a priori construction. (2) Precisely because theory is the image of the universal present in facts, reality cannot be ignored. You need to know facts. The idea that theory is still valid even if not applicable, contradicted by facts, is not true. (3) Theory is not an abstract model that applies to facts, but the very basis of empirical research, which you already intuitively have-to some extent-before examining the facts, both during their researching and after finishing that respective research. There is a dialectical relation between theory and facts: the research of facts depends on theory, but, at the same time, it influences theory, so that the theory from the end of one's research is no longer the same with the initial one."

(Coșeriu, 1996, p. 164-165; our translation)

In this respect, I will reproduce one more paragraph from the preliminary note which Coșeriu wrote for his book, Gramática, semántica, universales, published in 1978 (republished in 1987):

\footnotetext{
${ }^{3}$ The respective interview was republished, as an annex, in Integral Linguistics, the interview-book edited by Nicolae Saramandu in the '90s (see Coșeriu, 1996).
} 
“La teoría, en su sentido primario y genuino, es aprehensión de lo universal en lo concreto, en los «hechos» mismos. No hay, por consiguiente, ni distancia ni conflicto entre «hechos» (o investigación «empírica») y teoría, sino que la investigación empírica y la teoría son dos formas complementarias de la misma actividad. Una presentación e interpretación racional de un hecho es al mismo tiempo una contribución a la teoría; y una teoría auténtica es al mismo tiempo interpretación racional de «hechos»."

(Coșeriu, 1987, p. 10)

This idea, regarding reciprocal influence, from theory to the study of facts and the other way round, was suggested (or confirmed) to Coșeriu by an aesthetic conception. If Benedetto Croce had stated that in art intuition coincides with expression, John Dewey, however, stated that expression, even if it starts from intuition, turns against the latter and corrects it, refines it etc. The Romanian scholar loved the idea so much, that he adapted it to the issues that he was mainly interested in (see Munteanu, 2015, p. 137).

\section{An intratextual ideatic contamination}

But let us go back to that phrase (quoted above) which Coșeriu attributes to the great thinker José Ortega y Gasset: "When speaking about this aberration of the inapplicable theories, the Spanish philosopher Ortega said: «Una teoria que no se aplica no es una teoría, es una estupidez»". Since that was an oral presentation, we do not have any exact reference to a certain text from Ortega y Gasset's (extended) work. There is almost no doubt that Coșeriu had no written note at hand, but rather his memory (otherwise, exceptional) to count on. The fact that the Romanian linguist presented the public the quote in Spanish, not in Romanian, would plead for a faithful rendering of Ortega's words. And still, it seems that this time, his memory played tricks on him, but somehow in a motivated way, I would say. We will see how in what follows.

One might believe that, having the series of Ortega y Gasset "complete works" (Obras Completas) in $p d f$ format at hand, fact which allows you to check very quickly how many times the words teoria, aplica, estupidez appear in each volume, it is very easy to find the respective quote. However, it is not the case. Such researches, which I have done on the whole corpus, did not reveal anything ${ }^{4}$. Only after having thoroughly read all the existing Romanian translations (summing up to 15 volumes; Ortega y Gasset, 1972, 1973a, 1995, 1997a,b, 1999a,b,c,d,e, 2000, 2001, 2002, 2004, 2007) have I discovered what might be the source of this "mysterious" quotation. The revelatory context-made up of two sequences found in adjoining chapters-is found in Una interpretación de la historia universal (en torno a Toynbee), one of Ortega's books or, as translated in English, An Interpretation of Universal History. Thus, in chapter 10, when criticizing the empirical method of Arnold Toynbee, a British historian (who had wrongly related the birth of some past civilizations to some races), Ortega y Gasset states the following:

"Parenthetically, the other day, in order not to seem to be making a charge against Toynbee, this man of the empirical method who does not know what to do with so clear a fact as this and one which he can do no less than recognize as a fact, I did not say that the present theory and methodology of knowledge know perfectly well that the same thing happens to this empirical method as happened to those taxes imposed in Rome; the famous text of a professor in Salamanca says that they began by not existing. There is no empirical method in the sense that Toynbee pretends. All science is constructive, and construction is the opposite of empiricism; therefore, empiricism is contrary to method. The role that facts have in the construction of a theory is something else."

\footnotetext{
${ }^{4}$ Here is another proof that man cannot (yet) be replaced wherever and in any respect by computer. The latter can be programmed to find / identify certain things, but it cannot discover (for the time being) certain relations between those things, the way man does it, especially in the fields in which meaning plays a determining role.
} 
At this point, the following sentence leaps to the eye: "the same thing happens to this empirical method as happened to those taxes imposed in Rome; [...] they began by not existing" ".... a ese método empirico le acontece lo que a los impuestos en Roma [...], que es que empiezan por no existir"). As seen, the verb a aplica 'to apply' is only found in the Romanian translation ("acestei metode empirice i se intîmplă ce se întîmpla cu impozitele la Roma [...], se aplică, dar nu există”; Ortega y Gasset, 1999c, p. 271]); in the Spanish original, the meaning would be the following: 'start by not existing' ${ }^{6}$. Even if the Romanian translator rendered the meaning correctly, his version is less faithful and could be misleading in this case. However, the continuation is important, in which the term theory is found: "All science is constructive, and construction is the opposite of empiricism; therefore, empiricism is contrary to method. The role that facts have in the construction of a theory is something else". Indeed, in this paragraph, but even further in the same volume (see Ortega y Gasset, 1973b, p. 240), Ortega's conception about theory seems to be compatible (broadly speaking) to that of Coșeriu; so, it is possible that this paragraph may have drawn the Romanian scholar's attention first. But we have not got yet to the point we are interested in, namely at a sentence similar to that uttered by Coșeriu in that lecture. Well, in the adjoining chapter 11, when criticizing Toynbee again (for he had not granted drought the appropriate mythological meaning, as he had done with flood), Ortega makes, at one point, this comment, in a long footnote:

"When I alluded the other day to the myth of the Flood I referred of course to this SumerianAcadian tradition, which was what we were talking about. On what to call that myth, I do not suppose that a basis of reality can be denied. On the contrary. Nothing is myth unless it carries within itself the substance of a real human experience. When this is lacking it is not called a myth but simply «a bit of foolishness». It is a pity and a shame that these observations must be made and these reservations set forth; they ought to not be necessary for people who are even halfway cultured, but I do not know what there is in the intellectual air of Spain today; it seems as though there were suspended in it an ignorance and a demented insipidity which are truly pitiable and which oblige one to talk all these grotesque precautions."

(Ortega y Gasset, 1973b, p. 259-260) ${ }^{7}$

Consequently, the original context (introduced, just as in the other paragraph, by the expression el otro dia 'the other day') may be this one, referring to myth: "Nothing is myth unless it carries within itself the substance of a real human experience. When this is lacking it is not called a myth but simply «a bit offoolishness»". The myth itself is an explanation, a kind of "naive theory" regarding reality; this is how

\footnotetext{
${ }^{5}$ Here and in what follows the italicised words are mine. In the original, the text reads as such: "Entre paréntesis. El otro día, por no parecer que hacía una carga sobre Toynbee, este hombre del método empírico pero que no sabe qué hacer con un hecho como este, tan claro y que, naturalmente, no puede menos de reconocer como hecho, no dije que la teoría del conocimiento y la metodología actuales saben perfectamente que a ese método empirico le acontece lo que a los impuestos en Roma, según el famoso texto de un profesor de Salamanca, que es que empiezan por no existir. No hay método empírico en el sentido que pretende Toynbee. Toda ciencia es constructiva y la construcción es lo contrario del empirismo; por eso empirismo es lo más contrario que cabe del método. Otra cosa es el papel que tengan los hechos en la construcción de una teoría” (Ortega y Gasset, 1965b, p. 182).

${ }^{6}$ In a lecture from 1940, Ortega referred to the respective Spanish text (published around 1900) on the Roman law (and on the words regarding taxes), considering it a naïve text (see Ortega y Gasset, 1984, p. 44-45).

${ }^{7}$ In the original: "Cuando el otro día aludí al mito del diluvio me refería, claro está, a esta tradición sumerio-acadia, que era de lo que hablábamos. Sobre que llamar a algo mito no supone que se le niegue un fondo de realidad. Todo lo contrario. Nada es mito si no lleva dentro la médula de una experiencia humana real. Cuando esto falta no se le llama «mito», se le llama simplemente «tontería». Es una pena y una vergüenza que sea menester hacer estas observaciones y poner estas reservas, que debían ser innecesarias para personas medianamente cultas, pero yo no sé qué hay en el aire intelectual de España hoy que parece que en él están suspendidas una ignorancia y una insipidez demente verdaderamente penosas, que obligan a tomar todas estas precauciones grotescas" (Ortega y Gasset, 1965b, p. 197-198).
} 
the juxtaposition of the two concepts-'theory' ${ }^{\text {' }}$ and 'myth' -, as well as their substitution operated by Coșeriu would be justified. In the Spanish original the word tonteria (which rhymes with teoria) appears, not estupidez: "Nada es mito si no lleva dentro la médula de una experiencia humana real. Cuando esto falta no se le llama «mito», se le llama simplemente «tontería»". Coșeriu may have done the synonymic replacement under the effect of the term insipidez, found, in the same commentary, a little further in the text, in a sentence about ignorance, as well: "...una ignorancia y una insipidez demente verdaderamente penosas" ("an ignorance and a demented insipidity which are truly pitiable").

Taking as a model terminological syntagms already existing in linguistics, such as lexical contamination and phraseological contamination, we could refer here to a kind of intertextual ideatic contamination, since Coșeriu seems to have blended in one sentence two ideas found in separate paragraphs from the same philosophical work.

Given Coșeriu's passion for history in general, he must have read - as soon as he had the opportunityUna interpretación de la historia universal (en torno a Toynbee), as well as Historia como sistema (which he had already quoted, in 1957, in Sincronia, diacronia e historia). If I am fairly sure regarding his reading of the book mentioned, however, I do not know the distance in time (with an impact on memory) between the moment of the respective reading and the moment of the quoting occasioned by his lecture in Cluj. Anyway, such investigations, once finalized, bring us the same satisfactions that we live, for instance, when we discover (and propose) a new etymology.

\section{Ortega y Gasset and theory as imaginary construction}

At this point, we wonder if Coșeriu would have shaped, following his readings, a true opinion regarding the way in which Ortega understood the concept of 'scientific theory'. In the absence of a more extensive research on this issue (since I have not discovered at least some joined paragraphs written by Coșeriu about Ortega yet), we can only make here some assumptions more or less justified.

If Coșeriu had read certain books of José Ortega y Gasset (En torno a Galileo, La idea de principio en Leibniz y la evolución de la teoria deductiva, Sobre la razón histórica, etc.), he may have observed that the Spanish philosopher would not associate 'theory' with 'stupidity' (nor as tonteria, nor as estupidez), not even when the former had hardly any connection with reality. According to Ortega, theory represents a construction of a scientist's imagination, a mental construction meant to guide research (see Ortega y Gasset, 1984, p. 64). In fact, in his book, An Interpretation of the Universal History, a few paragraphs away from the place examined, Ortega insists on the character of imaginary construction of scientific theories. Referring to one of his own ideas, according to which "physical surroundings engender a civilization", Ortega considers it excellent, adding the following:

"But that idea is not empirical; it is completely the opposite, it is a hypothesis, and every hypothesis is a construction, and because of this [it is authentic science,] it is an authentic theory. In so far as they merit that exigent name, ideas are never a mere reception of presumed realities, but they are constructions of possibilities; therefore they are pure bits of imagination, or fine ideas of our own, as Plato of Athens son of Ariston found once and forever, twenty-four centuries ago; a discovery which, in my understanding, is without possible comparison with any other, the most sublime and efficacious one which has been made up to now on the planet we occupy, and which today, more than ever, constitutes the alpha and omega of every scientific exercise."

(Ortega y Gasset, 1973b, p. 240) ${ }^{9}$

\footnotetext{
${ }^{8}$ Undoubtedly, Ortega discusses about theory (or theories) in (many) other places (see, for example, Ortega y Gasset, 1999d, p. 84-85 and 116), but nowhere else in his work have I found the "inapplicable theory" related to stupidity.

${ }^{9}$ In the original: „Pero esa idea no es empírica; es todo lo contrario, es una hipótesis, y toda hipótesis es una construcción, y por eso es auténtica ciencia, por eso es auténtica teoría. Las ideas, en cuanto merecen este exigente nombre de ideas, no son nunca mera recepción de presuntas realidades, sino que son construcciones de posibilidades; por tanto, puras imaginaciones
} 
But since Coșeriu was mainly interested in the humanistic or cultural sciences, his way of tackling the problem (also mentioning Ortega y Gasset) is justified. Starting from the concept of "primary knowledge" (launched by Husserl), Coșeriu was convinced that-in the case of human sciences-the scientist has a sure intuition regarding cultural activities, since he is the subject (author) of these activities. Thus, in the case of linguistics (seen as a science of culture), a linguist starts or should always start from his exact intuition (unreflective knowledge) as a speaker. For this reason (and in this context), Coșeriu states that a theory that has no connection with the reality (of language) is „una estupidez”. What is more, he would use the term hypothesis only about the natural sciences, i.e. he used it exclusively for the field in which such a "theory" is abandoned or rejected if, following the experiment, it does not correspond at all to the reality investigated (see Coșeriu, 1992a, p. 11 or 2000a, p. 49-54).

It is true that Ortega y Gasset mainly refers to natural sciences (and also formal or mathematical sciences) when talking about theories as constructions of imagination. This is mainly seen in the studies he dedicated to some great thinkers, such as Galileo and Leibnitz. For instance, in Ortega's opinion, one of Galileo's greatest merits derives from the fact that he proved-through his own research in physics, by constructing a "reality" mentally and ideally-that science is both the result of imagination and observation, a "discovery" (or "invention") which the Spanish philosopher considers valid for the field of historical sciences, as well:

"Having that background in mind, I hold the conviction that we are now approaching a splendid flowering of the historic sciences, thanks to the fact that historians will resolve to confront historical facts just as, mutatis mutandis, Galileo confronted physical facts. They will become convinced that science-by which I mean the entire body of knowledge about things, whether corporeal or spiritual —is as much a work of imagination as it is of observation, and that the latter is not possible without the former; in short, that science is a process of construction."

(Ortega y Gasset, 1958, p. 15)

Thus, due to its imaginative character, science becomes a sister of poetry, with the remark that-adds Ortega-between Galileo's and a poet's imagination there is a radical difference: Galileo's imagination is an exact one.

Ortega is even more explicit in his book about Leibnitz, in which he deals, among other things, with the features of modern science, with a special focus on "the physical theory", about which he states ("in colloquial terms", as he admits it) the following: "what physical theory tells us, its content, has nothing to do with the reality of which it speaks." (Ortega y Gasset, 1971, p. 30) ${ }^{11}$. The particularities of this type of intellectual exercise are presented in this way:

"The way of thinking practiced by «physical theory» begins by enclosing that theory within itself and creating in its imaginary ambit a whole world — a system, an order or series-of objects which bear no resemblance to real phenomena. That imaginary intratheoretical system, by the very fact that is imaginary (like all mathematics) manages to be unequivocal."

\footnotetext{
nuestras o ideas puras, según averiguó hace veinticuatro siglos, de una vez para siempre, Platón de Atenas, hijo de Aristón; averiguación que, a mi entender, es, sin comparación posible con ningún otro, el descubrimiento más sublime y eficaz que se ha hecho hasta ahora en el planeta que habitamos y que hoy más que nunca constituye el alfa y omega de todo ejercicio científico" (Ortega y Gasset, 1965b, p. 184).

${ }^{10}$ In the original: „Pues bien, yo tengo la convicción de que se avecina un espléndido florecimiento de las ciencias históricas debido a que los historiadores se resolverán a hacer mutatis mutandis, frente a los hechos históricos, lo mismo que Galileo inició frente a los físicos. Se convencerán de que la ciencia, se entiende toda ciencia de cosas, sean éstas corporales o espirituales, es tanto obra de imaginación como de observación, que esta última no es posible sin aquella—en suma, que la ciencia es construcción” (Ortega y Gasset, 1964, p. 17).

${ }^{11}$ In the original: “...en términos vulgares: lo que la teoría física nos dice, su contenido, no tiene que ver con la Realidad de la cual nos habla” (Ortega y Gasset, 1965a, p. 78).
} 
(Ortega y Gasset, 1971, p. 32) $)^{12}$

Through experiment, the order of "fantastic" objects is compared in an unequivocal manner to that of real phenomena with a view to determining the extent to which the latter produce an isomorphic system with the system of the former. Thus, it is experiment (when the result is a positive one), and not similarity, the one which warrants the correspondence between the two series / systems (cf. also Ortega y Gasset, 1963, p. 68).

To Ortega, Plato is the one who anticipates modern science through his "method", and not Aristotle. The Stagirite starts (when it comes to "truths") from public opinion or from "common sense", keeping himself close to things and considering that the full proximity of mind to reality is assured by sensation. On the contrary, Plato's way of thinking is totally different:

"When Plato wants to know a thing that is close to him, his first action is to run off in the opposite direction, separate himself from it completely, go beyond the stars, and then, coming back as from a «supercelestial place», he sees what can be said with meaning about the things of this world which are so meaningless. This Platonic fight in order to approach seems to me the most inspired invention of a theoretic nature which has been produced on this planet; nothing else can even be compared to it."

(Ortega y Gasset, 1971, p. 130) ${ }^{13}$

In other words, facts (like some hieroglyphs which have to be interpreted in order to get to the message behind them) cover authentic reality. So as to reach it, the scientist withdraws in himself first, constructs a pure imaginary reality, and later he comes back (abandoning his mental isolation) with the "theory" he thus constructed, comparing it with the real surrounding facts. If the facts of the reality imagined are in accordance with the real surrounding facts, it means that reality (covered by the facts-hieroglyphs already deciphered) was discovered (see Ortega y Gasset, 1958, p. 12-13).

Obviously, the fact that a genius invention - the method of building theory in imagination -is useful to science in general does not mean that all the theories produced in this way are valid. (One can find numerous wrong explanations even at Plato.) For example, Ortega himself-despite his admiration for the famous French philosopher-refutes Descartes' theory about 'consciousness' (see Ortega y Gasset, 1984, p. 45 et seq.), precisely because it proves to be only an imaginary construction.

In such cases, in order to be more rigorous, the Spanish philosopher mentions one of his own dearest distinctions, that between 'ideas' and 'beliefs' (see Ortega y Gasset, 1999b). Just as man is certain (without usually paying attention to this detail) that the earth which he steps on bears his weight, or that, when getting out of the house, he will see the same well known street, he can trust the power of reason as such, without necessarily trusting the ideas created by it. Beliefs (which, in Ortega's view, make up the authentic culture) confer certainty to our life, while ideas do not necessarily have this quality. Theory (or "idea") is, in principle, practicable or applicable (and the serious part of a theory is represented by its applicability, its praxis), but-as Ortega insists-theory in itself is non-reality and imagination (see Ortega y Gasset, 1984, p. 34).

We should also clarify at this point why Ortega stated (see supra) that history (as a science) functions similarly to physics, too, operating with realities constructed by imagination. This analogy is valid only as

\footnotetext{
${ }^{12}$ In the original: "El modo de pensar que ejercita la «teoría física» comienza por encerrar a esta dentro de sí misma y crear en su ámbito fantástico un mundo-sistema, orden o serie-de objetos que no se parecen nada a los fenómenos reales. Ese sistema imaginario intrateórico, por lo mismo que es imaginario (como toda matemática), logra ser inequívoco" (Ortega y Gasset, 1965a, p. 80).

${ }^{13}$ In the original: "Cuando Platón quiere conocer una cosa que está a su vera, lo primero que hace es echar a correr en dirección opuesta, alejarse infinitamente de ella, irse más allá de los astros, y desde un «lugar supraceleste», viniendo en retorno, ver qué se puede decir con sentido sobre las cosas de este mundo que tanto carecen de él. Esta platónica fuga para acercarse me parece la invención más genial que en el orden teorético se ha hecho en el planeta, sin que quepa comparársele ninguna otra” (Ortega y Gasset, 1965a, p. 156-157).
} 
a starting point. When confronted with the problem of bodies moving (in various ways and directions), Galileo needed to establish a scheme or diagram of movement, to "imagine" - at first-an essential and permanent structure, which was to correspond later to the diverse movements he observed. Otherwise, the science of physics would have been impossible. In Ortega's opinion, history has to operate with a similar concept, namely with an objective structure of life, a kind of diagram of human life in general (see Ortega y Gasset, 1958, p. 18-19). Consequently, the mission of history would be, for him, to study the extent to which this structure had evolved through epochs, the changes it recorded during the evolution / becoming of man (see Ortega y Gasset, 1958, p. 29). Thus, the historian's work is, in fact, that of mentally reconstructing the objective conditions in which some major events happened. It is necessary for a historian to interpret, to act hermeneutically, being forced-whenever he wants to understand, for instance, a document from an old epoch - to consider or to find out as much as possible from the respective author's life (Ortega y Gasset, 1958, p. 17). The studies which Ortega y Gasset dedicated to Velázquez and Goya, two famous Spanish painters, are a case in point (see Ortega y Gasset, 1972).

As a matter of fact, the hermeneutics practised (and theorised) by Ortega is quite similar to the hermeneutics practised (and theorised) by Robin George Collingwood, especially when it comes to what the British philosopher would call "the re-enactment of the past thought in the historian's own mind", "the incapsulation of the past into the present" etc. Coșeriu himself also adhered to such a hermeneutics, putting it at work in order to elucidate some issues of etymology or of history of language (see Munteanu, 2013).

\section{Linguistic idealism and realism}

Since I started from Coşeriu and from linguistics, I should end in a similar way, by pointing out another convergence between the conception of the Romanian scholar and that of Ortega y Gasset (cf. Munteanu, 2019b). Coșeriu affirmed, on different occasions, that (linguistic) idealism is the most appropriate orientation for those who study aspects of language: "Yes, linguistic idealism, which is not idealism to me, but linguistic realism, as Mr. Copceag later said in an article" (Coșeriu, 1996, p. 10) ${ }^{14}$. Even if tributary, to a great extent, to idealism (mainly seen as a philosophical conception) ${ }^{15}$, Coșeriu accepted his linguistic doctrine to be characterised by the phrase "linguistic realism", for (as he used to say) he had constructed his theory in a coherent and unitary way, always starting from the reality of language ${ }^{16}$ and criticising the ones who had acted the other way round, that is by a "genuine transitus ab intellectu ad rem" (Coșeriu, 1997 a, p. 15$)^{17}$.

Let us remark that these two concepts (orientations) — 'idealism' and 'realism' — are not antagonistic not even in philosophy as such, once they are properly understood. José Ortega y Gasset had made some interesting observations concerning the inadequate use of the term idealism in the year 1910 (in a study on aesthetics, Adán en el Paraiso ["Adam în Paradis"]). He stated that (in his contemporaneity) was considered an idealist "the one who tries to introduce in the natural environment projects suitable to other climates, the one who wanders asleep through the world" ("el que trata de introducir en el clima ambiente proyectos adecuados a otros climas, el que camina dormido por el mundo"), that is, a romantic and a dreamer. The Spanish philosopher insisted on his rendering the correct interpretation of the term:

\footnotetext{
${ }^{14}$ In an honorary article from 1981 (published in Spanish), Dumitru Copceag had proposed the term linguistic realism to designate Coșeriu's linguistic theory (see Copceag, 2002, p. 100).

${ }^{15}$ Let us mention the fact that - paraphrasing the title of a famous work belonging to Karl Vossler, Positivismus und Idealismus in der Sprachwissenschaft (published in Heidelberg in 1904) - the linguist K. Rogger wrote the article Idealismus und Realismus in der Sprachwissenschaft (in "Zeitschrift für romanische Philologie", 75 (5-6), 1959, p. 403-438).

${ }^{16} \mathrm{See}$, for instance, Coșeriu’s mention, back to the '60s, when he was constructing "una teoría lingüística coherente y, al mismo tiempo, conforme al objeto lenguaje” (Coșeriu, 1967, p. 7).

${ }^{17}$ An idea differently stated, as follows: "Los aparentes conflictos entre la razón y la realidad son siempre conflictos de la razón consigo misma, pues no es la realidad la que debe adecuarse al intelecto, sino viceversa” (Coșeriu, 1973, p. 15-16).
} 
"Historically speaking, the word idea comes from Plato. And Plato is the one who named the mathematical concepts ideas. And he thus named them simply and exclusively because they are some mental instruments which serve the construction of concrete things. Without numbers, without plus and minus, which are ideas, those supposedly sensitive realities which we call things would not exist for us. Consequently, for an idea, its application to the concrete, its capacity to be realised is essential. Therefore, a genuine idealist does not copy the naïve ambiguous thoughts that cross his brain, but dives fervently in the chaos of the supposed realities and looks for an orientation principle in them in order to master them, in order to fully dominate res, things, which are his unique preoccupation and his unique muse. Truly speaking, idealism should be called realism."

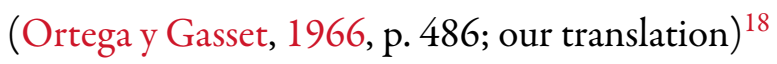

Coșeriu and Ortega's points of view are, at least partially, different. Coșeriu is mainly an Aristotelian, when it comes to knowledge and language, while Ortega is a Platonic in these respects, as well. "Seizing the universal in concrete facts" is the red thread of Coșeriu's conception, and this can be observed from the way in which he defines either 'linguistic signification', or 'theory', or '(artistic) literature' (see Munteanu, 2010, p. 112-113). Following Aristotle, Coșeriu was convinced that significations (or concepts) are born through an intellectual operation named by the Stagirite (in De anima) "the knowledge of indivisible" (nóesis tôn adiairéton or, in the scholastic terminology, apprehensio simplex), an operation through which the unitary intuition of a mode of being, or, in other words, the essence of things, is obtained (see Munteanu, 2012). On the contrary, Ortega applies (or accepts) Plato's "recipe" not only when building theories, but also when dealing with significations / concepts (cf. Ortega y Gasset, 1999d, p. 391-398). Ortega states that, in order to know a thing "caught" in the permanently moving reality, it is necessary that-nevertheless, starting from it by abstracting some features-to withdraw in ourselves (in Plato's "world") and elaborate the corresponding concept (or "idea"). When coming back into our world, we direct the concept / idea to the thing in order to know it better (Ortega y Gasset, 1984, p. 100-115). For a deeper understanding of the whole issue, we should present in extenso Ortega's theory on knowledge, his conception on intellect (with its logicality vs. the illogicality of reality) ${ }^{19}$ etc., but we cannot go any further, since the discussion would go beyond the frame of reference we first had in mind $^{20}$.

\section{Conclusions}

Let us remember that, in Coșeriu's vision, theory (especially when referring to the domain of humanities) "is not an arbitrary and abstract construction" (see supra, Sec. 2). Considering the things presented before,

\footnotetext{
${ }^{18}$ In the original: "Históricamente, la palabra idea procede de Platón. Y Platón llamó ideas a los conceptos matemáticos. Y los llamó así pura y exclusivamente porque son como instrumentos mentales que sirven para construir las cosas concretas. Sin los números, sin el más y el menos, que son ideas, esas supuestas realidades sensibles que llamamos cosas no existirían para nosotros. De suerte que es esencial a una idea su aplicación a lo concreto, su aptitud a ser realizada. El verdadero idealista no copia, pues, las ingenuas vaguedades que cruzan su cerebro, sino que se hunde ardientemente en el caos de las supuestas realidades y busca entre ellas un principio de orientación para dominarlas, para apoderarse fortísimamente de la res, de las cosas, que son su única preocupación y su única musa. El idealismo verdaderamente habría de llamarse realismo" (Ortega y Gasset, 1966, p. 486).

${ }^{19}$ In Ortega's opinion, intelligence (or reason) functions in a logical manner (for intellect is the only one in the Universe which is led by the principle of identity). Since it has been long believed that everything that is real is also rational (or, in other words, reality and reason have a common structure or fibre; otherwise, knowing the former by the latter would not be possible), there is the tendency that in the process of knowledge reality should be adapted to intellect, and not the other way round (see Ortega y Gasset, 1984, p. 113).

${ }^{20}$ Cf., however, Martínez del Castillo (2011), for an outline of Ortega y Gasset's conception. Nevertheless, I am sceptical about the way in which J.G. Martínez del Castillo-in order to develop a lingüistica del decir-combines Coșeriu's ideas about language with those of Ortega.
} 
we could conclude that Ortega y Gasset, even if he saw in theory "an imaginary construction"21, would have agreed with the conception that a theory must not be "arbitrary". When building a theory, one always starts, more or less, from reality. As to what the different philosophical "substratum" of the two scholars is concerned, it seems that the differences are not that irreconcilable... In this respect, an aphorism of the philosopher A.N. Whitehead is worth mentioning: Aristotle "dissected fishes with Plato's thoughts [=ideas] in his head." (Whitehead, 1967, p. 107). That means-as the British philosopher explains-that the Stagirite, though having started from Plato's theoretical activity, learnt to go "beyond theory to direct observation of details", modifying, correcting or infirming his master's ideas.

\section{Bibliography}

Copceag, D. (2002). „Realismul lingvistic” sau doctrina științifică a lui Eugenio Coseriu [1981], translated by Eugenia Bojoga, in "Limba română" (Chișinău), 12 (10), p. 100-107.

Coșeriu, E. (1967). Teoría del lenguaje y lingüistica general. Cinco estudios [1962], segunda edición, Editorial Gredos, Madrid.

Coșeriu, E. (1973). Sincronía, diacronía e historia. El problema del cambio lingüistico [1957], segunda edición, revisada e corregida, Editorial Gredos, Madrid.

Coșeriu, E. (1977). Antrittsrede an der Heidelberger Akademie der Wissenschaften, in "Jahrbuch der Heidelberger Akademie der Wissenschaften" [für 1977], p. 107-108.

Coșeriu, E. (1987). Gramática, semántica, universales. Estudios de lingüistica funcional [1978], segunda edición revisada, Editorial Gredos, Madrid.

Coșeriu, E. (1992a). Principiile lingvisticii ca știință a culturii, in "Apostrof”, 3 (11), p. 11 and 14.

Coșeriu, E. (1992b). Principiile lingvisticii ca știință a culturii, in vol. Omul și limbajul său. Studia linguistica in honorem Eugenio Coseriu (= "Analele științifice ale Universitații «Al. I. Cuza» din Iași”, Serie nouă, Secțiunea III, e, Lingvistică, tom XXXVII-XXXVIII, 1991-1992), Iași, p. 11-19.

Coșeriu, E. (1993). Discurso pronunciado con motivo de su investidura como doctor honoris causa, in vol. Discursos pronunciados en el acto de investidura de doctor honoris causa del Excelentísimo Señor Eugenio Coseriu, Universidad de Granada, Granada, p. 21-35.

Coșeriu, E. (1996). Lingvistica integrală, interview with Eugeniu Coşeriu, taken by Nicolae Saramandu, Editura Fundației Culturale Române, București.

Coșeriu, E. (1997a). Sincronie, diacronie și istorie. Problema schimbării lingvistice, Romanian version by Nicolae Saramandu, Editura Enciclopedică, București.

Coșeriu, E. (1997b). [Principiile cercetării de tip umanist], in “Analele Academiei Române”, year 126 (1992), series V, vol. III. [Editura Academiei Române, București], p. 277-278.

Coșeriu, E. (1999). Discurso de Investidura del Prof. Eugenio Coseriu, in vol. Discursos de investidura de „doctor honoris causa” de los profesores Carlos Castilla del Pino, Eugenio Coseriu, José Elguero Bertolini, Universidad Autónoma de Madrid, Madrid, p. 33-42.

Coșeriu, E. (2000a). Lecții de lingvistică generală, translation from Spanish by Eugenia Bojoga, foreword by Mircea Borcilă, Editura Arc, Chișinău.

Coșeriu, E. (2000b). The Principles of Linguistics as a Cultural Science, translation of Coșeriu (1992a) by Liviu Bleoca, in "Transylvania Review", 9 (1), p. 108-115.

Coșeriu, E. (2004a). Epistemologia lingvisticii, in vol. In memoriam Eugeniu Coșeriu, Editura Academiei Române, București, p. 87-94.

Coșeriu, E. (2004b). Despre principiile științei lingvistice, in E. Coșeriu, Prelegeri și seminarii la Universitatea „Lucian Blaga” din Sibiu, Editura Universității „Lucian Blaga”, Sibiu, p. 25-36.

Martínez del Castillo, J.G. (2011). Lingvistica rostirii. Logosul semantic și logosul apofantic [2004], edition, translation and foreword by Cristian Pașcalău, Scriptor \& Argonaut, Cluj-Napoca.

Munteanu, C. (2010). Lingvistica integrală ca Organon pentru cercetările privind limbajul, in "Limba română”, (Chișinău), 20 (11-12), p. 110-123.

Munteanu, C. (2012). Pentru o justă înțelegere a conceptului de «semnificat» la Eugeniu Coșeriu, in "Anuar de lingvistică și istorie literară", 51, Editura Academiei Române, București, p. 259-276.

Munteanu, C. (2013). Influența lui Robin George Collingwood asupra lui Eugenio Coseriu, in Catană-Spenchiu, A. \& Repciuc, I. (eds), Flores Philologie. Omagiu profesorului Eugen Munteanu, la împlinirea vârstei de 60 de ani, Editura Universității „Alexandru Ioan Cuza”, Iași, p. 442-460.

\footnotetext{
${ }^{21}$ Obviously, a scientist needs imagination in his activity, and not only as envisaged by Ortega y Gasset. For instance, John Dewey considered that imagination fills gaps, "rounds" the whole, when one's theory does not have access to all necessary empirical data (probably, similar to the way in which an archaeologist / restorer reconstitutes, for a museum, an ancient clay pot, of which only a few fragments were found).
} 
Munteanu, C. (2015). John Dewey și Eugeniu Coșeriu despre necesitatea exprimării (libere) în știință, in "Meridian critic" (Suceava), 24 (2), p. 133-138.

Munteanu, C. (2019a). Freedom and Libertinism in Culture. From José Ortega y Gasset to Eugenio Coseriu, in EIRP Proceedings, 14 [Danubius University Press, Galați], p. 421-424.

Munteanu, C. (2019b). Limbajul întreprețuireși disprețiire. Câteva aspecte, in “Limba română” (Chișinău), 29 (3), p. $100-106$. Ortega y Gasset, J. (1958). Man and Crisis, translated from Spanish by Mildred Adams, W.W. Norton \& Company, New York.

Ortega y Gasset, J. (1961). History as a System, and other Essays toward a Philosophy of History, with and Afterword by John William Miller, translated by Helene Weyl, W.W. Norton \& Company, New York - London.

Ortega y Gasset, J. (1963). Concord and Liberty, translated by Helene Weyl, W.W. Norton \& Company, New York.

Ortega y Gasset, J. (1964). Obras Completas, Tomo V (1933-1941), sexta edición, Revista de Occidente, Madrid.

Ortega y Gasset, J. (1965a). Obras Completas, Tomo VIII (1958-1959), segunda edición, Revista de Occidente, Madrid.

Ortega y Gasset, J. (1965b). Obras Completas, Tomo IX (1960-1962), segunda edición, Revista de Occidente, Madrid.

Ortega y Gasset, J. (1966). Obras Completas, Tomo I (1902-1916), séptima edición, Revista de Occidente, Madrid.

Ortega y Gasset, J. (1971). The Idea of Principle in Leibnitz and the Evolution of Deductive Theory, translated by Mildred Adams, W.W. Norton \& Company, New York.

Ortega y Gasset, J. (1972). Velázquez. Goya, translation by Dan Munteanu, preface by Andrei Ionescu, Editura Meridiane, București.

Ortega y Gasset, J. (1973a). Meditații despre Don Quijote and Gînduri despre roman, translation, preface, notes and chronological table by Andrei Ionescu, Editura Univers, București.

Ortega y Gasset, J. (1973b). An Interpretation of Universal History, translated by Mildred Adams, W.W. Norton \& Company, New York.

Ortega y Gasset, J. (1984). Historical Reason, translated by Philip W. Silver, W.W. Norton \& Company, New York - London.

Ortega y Gasset, J. (1995). Studii despre iubire, translation by Sorin Mărculescu, Humanitas, București.

Ortega y Gasset, J. (1997a). Spania nevertebrată. Schiță de reflecții istorice, translation from Spanish, notes and foreword by Sorin Mărculescu, Humanitas, București.

Ortega y Gasset, J. (1997b). Tema vremii noastre, translation from Spanish and preface by Sorin Mărculescu, Humanitas, București.

Ortega y Gasset, J. (1999a). Misiunea Universității, translation and preface by Andrei Ionescu, Editura Univers, București.

Ortega y Gasset, J. (1999b). Idei şi credințe (și alte eseuri de filosofie), translation from Spanish by Doina Lincu, Editura Ştiințifică, București.

Ortega y Gasset, J. (1999c). O interpretare a istoriei universale (pornind de la Toynbee), translation from Spanish by Esdra Alhasid, Editura Ştiințifică, București.

Ortega y Gasset, J. (1999d). Ce este fllozofia? Ce este cunoașterea?, with an introduction by Manuel García Morente, translation from Spanish by Sorin Mărculescu, Humanitas, București.

Ortega y Gasset, J. (1999e). Cîteva lecții de metafizică, translation from Spanish by Sorin Mărculescu, Humanitas, București.

Ortega y Gasset, J. (2000). Dezumanizarea artei (și alte eseuri de estetică), translation from Spanish, preface and notes by Sorin Mărculescu, Humanitas, București.

Ortega y Gasset, J. (2001). Omul și mulțimea, translation from Spanish and notes by Sorin Mărculescu, Humanitas București.

Ortega y Gasset, J. (2002). Europa și ideea de națiune (și alte eseuri despre unele probleme ale omului contemporan), translation from Spanish and notes by Sorin Mărculescu, Humanitas, București.

Ortega y Gasset, J. (2004). Originea și epilogul filozofiei (și alte eseuri filozofice), translation from Spanish and notes by Sorin Mărculescu, Humanitas, București.

Ortega y Gasset, J. (2007). Revolta maselor [1994], translation from Spanish by Coman Lupu, $3^{\text {rd }}$ edition, Humanitas, București.

Whitehead, A.N. (1967). Adventures of Ideas [1933], The Free Press, New York.

[Translated by Silvia Munteanu and Cristinel Munteanu] 